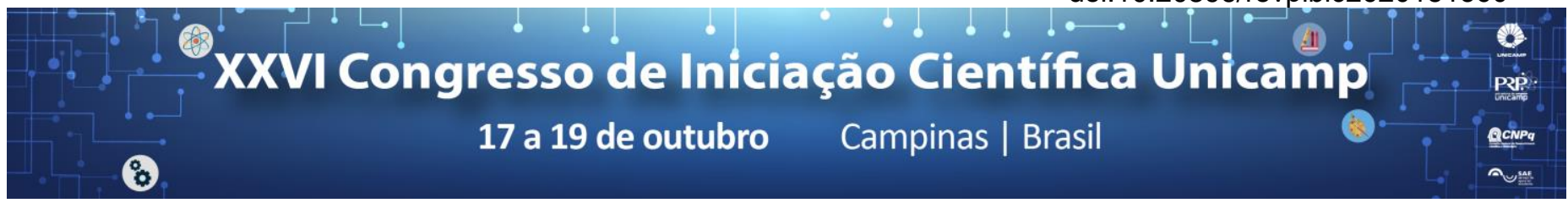

\title{
Implementação de um novo equipamento para a otimização de produção de membranas nanoporosas via anodização de alumínio
}

\section{Vinícius Serra Vianna*, Alexsandro S. E. da Cruz, Fanny Béron}

\section{Resumo}

Analizou-se o processo de formação e descolagem de membranas nanoporosas de óxido de alumínio. Produziu-se uma nova base de alumínio que permitiu fazer testes padronizados com as partes restantes de alumínio utilizada em anodizações anteriores, sem comprometer o material do laboratório. A nova base, junto com uma célula modificada, permitiu a realização de experimentos de descolagem da membrana anodizada após sua formação. $O$ trabalho analiza os dados obtidos nos experimentos e apresenta os processos de desenvolvimento do novo equipamento.

\section{Palavras-chave:}

Nanotecnologia, Anodização de alumínio, Membranas nanoporosas.

\section{Introdução}

Membranas nanoporosas de óxido de alumínio têm grandes aplicabilidades. Entretanto, 0 estudo do processo de formação dessas possui contratempos, entre eles, nota-se o alto custo dos discos de alumínio usados para crescer as membranas.

O projeto visou criar uma nova célula que pudesse reutilizar as partes restantes de alumínio de anodizações anteriores. Essas partes não tinham utilidade no laboratório. Assim, este procedimento permite a realização de novos testes relacionados à anodização, principalmente o estudo da descolagem da membrana de óxido do disco de alumínio.

Inicialmente, produziu-se uma peça que padronizou os pedaços de alumínio restantes em anodizações. Os pedaços eram bordas com espessuras variáveis. Com a nova peça, passaram a representar bordas de espessura contínua.

Com os pedaços simétricos em mãos modificou-se uma célula permitindo praticidade nos testes de descolagem.

O trabalho apresenta em detalhes os processos de anodização, de fabricação e idealização da nova célula, além dos dados nos testes de descolagem.

\section{Resultados e Discussão}

Os dados de potencial e corrente elétrica em função do tempo, juntos com as imagens obtidas com microscópio eletrônico de varredura, corroboram que os processos nos novos equipamentos condizem com os realizados em outros equipamentos.

Durante as anodizações notou-se que a densidade de corrente de pico dos processos com 0 novo equipamento foram similares aos resultados obtidos em anodizações com o disco inteiro em equipamentos respaldados. Dessa forma, inferimos que 0 novo equipamento se demonstrou apto aos testes. Assim, foi possível respeitar os dados dos testes de descolagem.

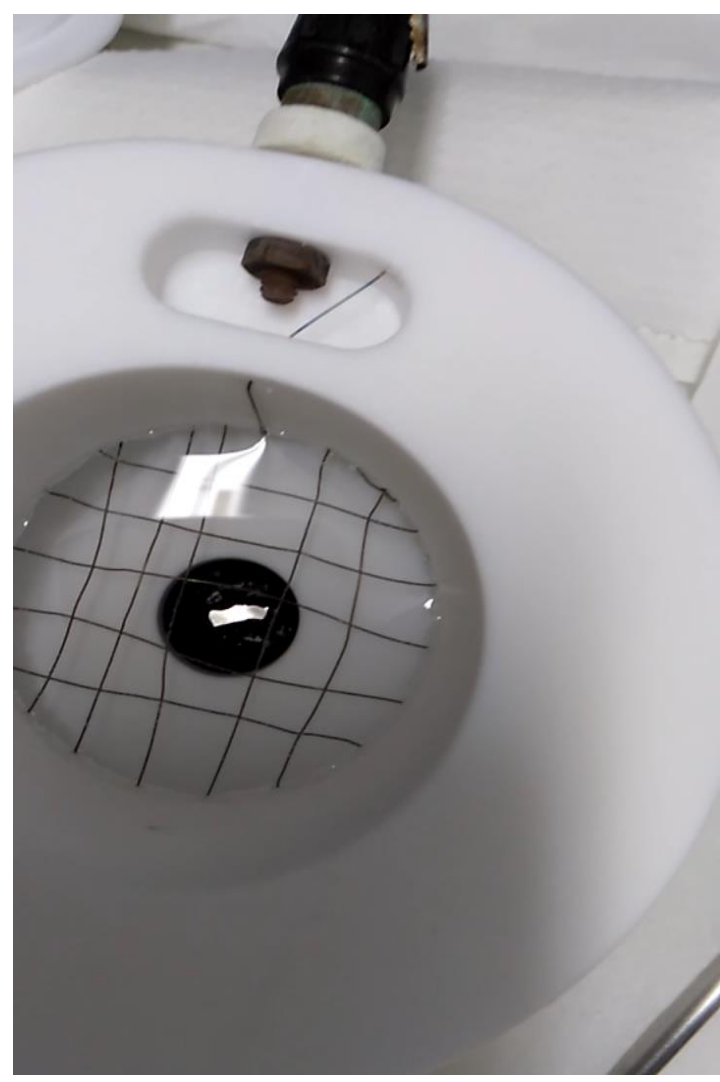

Figura 1. Processo de anodização feito com borda simétrica em célula modificada.

\section{Conclusões}

Conclui-se que a implementação de uma nova célula para anodizar pedaços de alumínio ocorreu com satisfação. Os testes de descolagem ocorreram sem impedimentos relacionados ao equipamento e aproveitou-se com excelência o material do laboratório, permitindo a prática do aprendido na literatura e abrindo possibilidades de testes com custo reduzido.

\section{Agradecimentos}

Essa pesquisa teve suporte do Laboratório de Materiais e Baixas Temperaturas. 